\title{
Invited review: Accelerating mammary gland involution after drying-off in dairy cattle
}

\author{
X. Zhao, ${ }^{1 *}$ B. Ponchon, ${ }^{1}$ S. Lanctôt, ${ }^{2}$ and P. Lacasse ${ }^{2}$ \\ ${ }^{1}$ Department of Animal Science, McGill University, Sainte-Anne-de-Bellevue, QC, Canada H9X 3V9 \\ ${ }^{2}$ Sherbrooke Research and Development Centre, Agriculture and Agri-Food Canada, Sherbrooke, QC, Canada J1M 0C8
}

\begin{abstract}
Bovine mammary gland involution, as a part of the reproductive cycle in dairy cows, is a very important remodeling transformation of the mammary gland for the subsequent lactation. There is considerable incentive to accelerate mammary gland involution to improve udder health, shorten the dry period, and simplify the management process by reducing dietary changes. The complex process of mammary involution is characterized by morphological changes in the epithelial cells and mammary tissue, changes in the composition of mammary secretions, and changes in the integrity of tight junctions. Involution is facilitated by elements of the immune system and several types of proteases and is coordinated by various types of hormones. This review first describes the involution process and then argues for the need to accelerate it. Last, this review focuses on various intervention methods for accelerating involution. Our aim is to provide a comprehensive overview of bovine mammary gland involution as well as potential techniques and new opinions for dry cow management.
\end{abstract}

Key words: lactation, milk synthesis, mammary, management

\section{INTRODUCTION}

The transition from lactation to a dry period is a very critical phase in the reproduction cycle of dairy cows. Dry cow management, including the length of the dry period, is important for the health, milk production, and fertility of dairy cows in subsequent lactations. The absence of teat stimulation and udder emptying triggers the mammary gland to regress during a remodeling process known as active involution or, simply, involution. This physiological event involves a decrease in the synthesis and secretion of milk components by

Received January 25, 2019.

Accepted April 22, 2019.

*Corresponding author: xin.zhao@mcgill.ca mammary epithelial cells, the renewal of a portion of the mammary epithelium, the activation of different proteases, and an increase in the permeability of tight junctions between epithelial cells. However, the exact elements triggering involution events have not been fully elucidated.

Once mammary gland involution is complete, the udder is more resistant to bacterial infections. In addition, a fast, active involution may render a shortened dry period feasible. Thus, a strategy to hasten the involution process would be beneficial to dairy farmers in terms of profitability and to dairy cows in terms of health. In this article, we review what happens in the bovine mammary gland during the transition from lactation to a dry period and describe various drying-off strategies that could be used to accelerate mammary gland involution.

\section{WHAT IS MAMMARY GLAND INVOLUTION?}

Mammary gland involution is defined as the process through which the gland returns to a nonlactating state. There are 3 types of involution: gradual involution is the regression of the lactation function during progression of a normal lactation, senile involution occurs at the end of a mammal's reproductive life, and active involution or initiated involution is the process that occurs in the mammary gland after cessation of milking during forced or natural weaning (Hurley, 1989).

Typically, a dry period in dairy cows can be divided into 3 stages. The first stage starts right after the final milk removal and corresponds to the moment of active involution, when the mammary gland undergoes a series of remodeling processes. The second stage is a stationary period, during which the mammary gland is in a resting state. The third stage is a period of preparation for the next lactation, during which the mammary gland undergoes redevelopment and begins colostrum formation (Hurley, 1989; Oliver and Sordillo, 1989). Active involution is fully initiated within $2 \mathrm{~d}$ after cessation of milking and seems to last approximately $21 \mathrm{~d}$ in the cow (Hurley, 1989). 
What triggers the involution process in cows is still uncertain. It has been suggested that mammary gland involution in goats is triggered by an increase in intramammary pressure, whereas withdrawal of the suckling stimulus seems to be more important in rodents (Fleet and Peaker, 1978). Additionally, the milk stasis that occurs after cessation of milking could lead to the accumulation in the gland of factors that inhibit milk synthesis and secretion by decreasing mammary epithelial cell activity and triggering involution. These factors are chemical in nature and include several potential candidates. One candidate was a protein of 10 to $30 \mathrm{kDa}$ present in the whey fraction of goat milk, named feedback inhibitor of lactation, and its infusion into the mammary gland depressed milk secretion in goats (Peaker and Wilde, 1996). However, to the best of our knowledge, feedback inhibitor of lactation has not been identified in cows. Instead, Silanikove et al. (2000) showed that $\beta$-CN 1-28 closed potassium channels, inhibited milk secretion, and affected the tight junction function. This fragment could initiate the mammary gland involution. However, additional experiments are needed for the confirmation. A more promising candidate could be serotonin. Stretching of the alveoli has been shown to induce the expression of the limiting enzyme (TPH1) for the synthesis of serotonin (Matsuda et al., 2004). Hernandez et al. (2008) showed that serotonin infusion reduced milk synthesis, whereas blocking the serotonin receptor increased milk synthesis, and the authors proposed serotonin as a feedback inhibitor of lactation in the bovine. In vitro, serotonin has been shown to suppress $\beta$-CN expression by inhibiting STAT5 activation (Chiba et al., 2014). Additional evidence to support the role of serotonin in mammary gland involution has been summarized in several recent reviews (Collier et al., 2012; Horseman and Collier, 2014; Hernandez, 2018). Whether other factors are also involved in triggering involution in cows still needs to be determined.

Active involution is a complex event that transforms the structure and composition of the mammary gland after intense milk production during the lactation period. This remodeling process is characterized by numerous cellular and molecular changes that lead to renewal of the mammary epithelial cell population. The changes involve a decrease in milk component synthesis, an increase in apoptosis of secretory alveolar cells, an increase in tight junction permeability between alveolar epithelial cells, the activation of several proteases in combination with the inactivation of their inhibitors, and the loss of cell-cell and cell-extracellular matrix contacts. These different physiological events during active involution are discussed next.

\section{Mammary Gland Involution Induces Morphological Changes in Epithelial Cells and Mammary Tissue}

The rapidity and degree of mammary gland involution vary across species. Such variations are best exemplified by the comparison between rodents (the most widely studied mammals) and ruminants. In rodents, mammary gland involution is characterized by a reduction in milk component synthesis (Quarrie et al., 1996), a marked decrease in the size and number of ducts, and a drastic reduction in epithelial cell numbers due to apoptosis $2 \mathrm{~d}$ after weaning (Walker et al., 1989; Guenette et al., 1994; Quarrie et al., 1996). Indeed, the secretory tissue regresses dramatically during involution and returns to a state close to that of the virgin mammary gland. Although a small number of epithelial cells are shed directly into the alveolar lumen, extensive apoptosis is mainly responsible for the reduction in mammary epithelial cell numbers during involution in rodents (Walker et al., 1989). The apoptotic epithelial cells are phagocytized mainly by macrophages and are enzymatically degraded in heterolysosomes (Walker et al., 1989). The number of macrophages is effectively enhanced in the mammary tissue during this period to support elimination of the apoptotic cells (Walker et al., 1989). A small proportion of apoptotic epithelial cells are also phagocytized by other epithelial cells (Walker et al., 1989). This is why there is an increase in the activity of lysosomal enzymes, such as cathepsin D, acid phosphatase, arylsulfatase, and $\beta$-glucuronidase, in both epithelial cells and macrophages during early involution in the rat (Helminen et al., 1968; Helminen and Ericsson, 1970). In both mice and rats, the dramatic increase in epithelial cell loss by apoptosis occurs during the first $3 \mathrm{~d}$ of involution (Walker et al., 1989; Guenette et al., 1994; Quarrie et al., 1996). This intense phase of apoptosis of the mammary epithelium is considered the first step of active involution in rodents and is reversible (Lund et al., 1996). Then, 3 to $4 \mathrm{~d}$ after weaning, the second and irreversible step of active involution is triggered and involves intense tissue remodeling through the action of different proteases and macrophages. Another feature of mammary gland involution in rodents is the increased appearance of large cytoplasmic vacuoles and vesicles containing protein globules and lipids (Walker et al., 1989; Guenette et al., 1994). These vesicles accumulate in the secretory epithelial cells because of the reduced secretion of milk components.

Unlike in rodents, the lobuloalveolar structure is maintained during involution in ruminants and particularly in cows (Akers et al., 1990; Capuco and Akers, 1999). The bovine mammary gland does not regress to 
the same extent as the rodent mammary gland does. There is no apparent loss of mammary cells during this remodeling process in dairy animals (Capuco and Akers, 1999). This difference relative to rodents may be explained partly by the fact that dairy cows are usually pregnant during the drying-off period. Therefore, the hormonal and local signals acting on mammary gland development during pregnancy may counteract those acting during involution in the cow. Indeed, the size and integrity of alveoli were maintained after $3 \mathrm{~d}$ of involution in pregnant mice, and concomitant pregnancy decreased the apoptosis rate and increased the proliferation rate of mammary epithelial cells observed compared with nonpregnant mice $3 \mathrm{~d}$ after weaning (Capuco et al., 2002). However, it has been shown that even in nonpregnant cows, the number of apoptotic bodies was only slightly increased during involution compared with the massive cell death that occurs in rodent involution, suggesting that a real species difference exists between rodents and ruminants.

In lactating ruminants, the mammary epithelium comprises a monolayer of cuboidal-shaped mammary epithelial cells that are well polarized, surrounded by myoepithelial cells, and circumscribed by a basement membrane (Holst et al., 1987; Singh et al., 2005). The area occupied by the alveolar lumen in the secretory tissue is predominant, whereas the stromal area is at its minimum and the epithelial area is at its maximum (Holst et al., 1987; Singh et al., 2005; Colitti and Farinacci, 2009). The alveoli are uniform, contain a large proportion of epithelial cells, and are distended and filled with milk (Wilde et al., 1997; Singh et al., 2005). The epithelial cells contain numerous small secretory vesicles and fat droplets, an extensive rough endoplasmic reticulum, a well-developed Golgi apparatus, and many mitochondria (Holst et al., 1987; Singh et al., 2005). The epithelial cells also contain many small vacuoles in their apical half, and the nucleus is centrally or basally located (Holst et al., 1987; Colitti and Farinacci, 2009). The microtubules are predominantly in the apical side of the epithelial cells and are oriented perpendicularly to the cell apex (Nickerson et al., 1982), indicative of their roles in the process of milk component secretion.

Once milking is stopped, numerous modifications in the composition of the mammary tissue and in the ultrastructure of the epithelial cells occur. These modifications reflect the changes in the secretory activity of the mammary gland. Overall, the number of organelles involved in milk component synthesis and secretion and the number of secretory vesicles decline abruptly, indicative of the decrease in mammary epithelial cell activity. In bovines, $2 \mathrm{~d}$ after cessation of milking, the rough endoplasmic reticulum is intact, but the number of mitochondria is reduced and the Golgi apparatus is less evident compared with during lactation (Holst et al., 1987). Large vacuoles appear within mammary epithelial cells and increase in number as involution advances, leading to condensing of the other organelles in the intracellular space (Holst et al., 1987). These vacuoles contain casein micelles or lipids, and some of the vacuoles arise from the coalescence of both lipid droplets and secretory vesicles (Holst et al., 1987). Casein micelles and lipid droplets accumulate in the cell because the fusion of the secretory vesicles to the apical membrane is altered. This alteration is due to impairment of the function of the cytoskeleton and particularly of microtubules, which are highly involved in the secretion process. Indeed, the microtubules are fewer and lose their perpendicular orientation within the apical cell membrane during involution compared with during lactation (Nickerson et al., 1982). As involution continues to progress, the rough endoplasmic reticulum is reduced and sparser (Holst et al., 1987), and the alveoli become smaller and collapsed (Singh et al., 2005). Nevertheless, the involution process is still reversible, as resuming milking at this stage will reinitiate milk production with minimal losses in milk production (Singh et al., 2015).

After $1 \mathrm{wk}$ of involution in cows, the relative proportion of epithelial tissue and stromal tissue is markedly changed. Although the epithelial area does not vary much during involution (Akers et al., 1990; Capuco et al., 1997), the luminal area decreases and the stromal area increases considerably (Capuco et al., 1997; Capuco and Akers, 1999). Finally, by 21 d, the majority of epithelial cells are in a nonsecretory state (Akers et al., 1990). Although it is still possible until d 28 to reinitiate milk synthesis by resuming milking, milk recovery declines rapidly and milk composition is altered (Singh et al., 2015).

The involution process of bovine mammary glands is heterogeneous. During the first $3 \mathrm{~d}$ after cessation of milking, both regressing alveoli and active alveoli are present (Singh et al., 2005). Even 1 wk after cessation of milking, some alveoli remain intact, whereas others degenerate and contain high proportions of sloughed cells and apoptotic cells (Wilde et al., 1997). The mammary parenchyma does not regress uniformly throughout the udder: involution begins in lower regions of the udder and extends progressively (Akers et al., 1990). Even though the cytoplasmic organelles involved in milk component synthesis are reduced, they are still present, and the epithelial cells seem to be capable of metabolic activity (Holst et al., 1987). This explains why mammary gland involution is partially reversible after several days of milk stasis in the cow (Noble and Hurley, 1999; Singh et al., 2015). 
Mammary gland involution is a period of intense cell turnover in ruminants. It has been shown in cows that mammary cell proliferation, as determined by Ki-67 staining, is greater during the dry period than during lactation and that the percentage of Ki-67-positive nuclei is higher during the late dry period than during the early dry period (Sorensen et al., 2006; Nørgaard et al., 2008). The proliferation rates of both epithelial cells and stromal cells increase from late lactation to the late dry period (Wall et al., 2005; De Vries et al., 2011). In contrast, the proportion of mammary epithelial cells positively stained by the terminal deoxynucleotidyl transferase dUTP nick-end labeling (TUNEL) assay, identifying the cells in apoptosis, is greater during the early dry period than during the late dry period (Sorensen et al., 2006). About 50\% of the epithelial cells are eventually lost during involution in bovines (Akers et al., 1990). It has been hypothesized that this apoptosis process during the dry period is aimed to discard nonfunctional or senescent cells (Capuco et al., 1997; Capuco and Akers, 1999; Sorensen et al., 2006). Mammary gland involution is significantly affected by concomitant pregnancy. Considering the fact that dairy cows are typically pregnant at the time of dry-off, Capuco et al. (2003) proposed the term "regenerative involution" to describe the processes of cell renewal and tissue remodeling that occur during involution with concomitant pregnancy.

\section{Mammary Gland Involution Modifies the Composition of Mammary Secretions}

The composition of milk starts to change during late lactation and is greatly modified after cessation of milking in dairy ruminants. These modifications in fluid composition are the consequence of the reduced activity of epithelial cells to synthesize and secrete milk components, the action of the protease plasmin in milk, and the increase in tight junction permeability.

First, epithelial cell activities are greatly reduced during mammary gland involution. At drying-off, mammary secretions are rich in specific milk fat, caseins, $\alpha-L A$, and $\beta-L G$ and contain a very low proportion of lactoferrin (Noble and Hurley, 1999). After cessation of milking, the composition is inverted, with lactose, milk fat, caseins, $\alpha-\mathrm{LA}$, and $\beta-\mathrm{LG}$ declining rapidly and lactoferrin being upregulated (Hurley, 1989; Noble and Hurley, 1999). As mentioned previously, the secretion of milk components is altered during involution because of the disorganization of the microtubule network. Moreover, the abundance and functionality of cytoplasmic organelles involved in milk component synthesis are reduced. The percentage of fat in mammary secretion decreases progressively as involution advances (Sordillo et al., 1987) owing to a reduction in specific milk fat secretion and synthesis. Similarly, the production and release of milk-specific proteins are greatly decreased. Concentrations of caseins, $\alpha-\mathrm{LA}$, and $\beta-\mathrm{LG}$ in milk are markedly decreased during the first half of the dry period (Hurley and Rejman, 1986; Aslam et al., 1994; Noble and Hurley, 1999). For instance, 1 wk after cessation of milking in cows, expressions of $\alpha-\mathrm{LA}$ and $\alpha_{\mathrm{S}_{1}} \mathrm{CN}$ decreased by 99 and $85 \%$, respectively, compared with their expressions during lactation (Wilde et al., 1997). The concentration of citrate, which is also an indicator of mammary epithelial cell activity, is reduced during the first 2 wk of involution (Nonnecke and Smith, 1984). These changes in milk composition during involution reflect the decrease in epithelial cell activity highlighted by the ultrastructural changes mentioned above. In addition, different types of milk caseins, in particular $\beta-\mathrm{CN}$, are degraded into smaller fragments under the action of the serine protease plasmin. This enzymatic catabolism contributes to decreased casein concentrations in mammary secretion during involution. Last, the changes in milk composition are also due to the change in the permeability of the tight junction barrier. This topic is discussed further in the next section.

\section{Mammary Gland Involution Involves the Impairment of Tight Junction Integrity}

The mammary epithelium, besides its secretory function, allows the delimitation between 2 fluids: the milk secreted by mammary epithelial cells and the interstitial fluid. Milk is rich in lactose and milk proteins such as caseins and contains low concentrations of sodium and chloride, whereas the interstitial fluid contains plasma proteins such as BSA as well as high concentrations of sodium and chloride (Nguyen and Neville, 1998). To maintain the separation between these 2 fluids, the mammary epithelium needs to be impermeable and act as a barrier. Such a barrier is formed by tight junctions among mammary epithelial cells. These junctions prevent the transit of milk components into the interstitial fluid and, reciprocally, the transit of interstitial components into milk (Stelwagen et al., 1997).

Tight junction permeability varies during the reproductive cycle and has an effect on milk composition. During pregnancy, mammary tight junctions are leaky in goats and cows (Fleet and Peaker, 1978). Before parturition, mammary secretion contains more proteins, sodium, and chloride and less lactose than true milk does (Nguyen and Neville, 1998), and the transepithelial potential difference between milk and blood is lower during late pregnancy than during lactation (Peaker, 
1977). These observations indicate that the interstitial components diffuse into milk and vice versa because mammary tight junctions are permeable. The composition of mammary secretions changes around calving due to the strengthening of the tight junctions (Linzell and Peaker, 1972). During lactation, mammary tight junctions are strongly sealed and form a highly impermeable barrier between milk and the interstitial fluid. The mammary epithelium thus allows the maintenance of ionic gradients between these 2 compartments. After cessation of milking, mammary tight junction integrity starts to be compromised after 20 to $21 \mathrm{~h}$ of milk accumulation in the ewe and the goat (Stelwagen et al., 1994; Castillo et al., 2008).

Disruption of tight junction integrity during weaning or cessation of milking triggers an exchange of different elements (ions, proteins, and carbohydrates) according to their concentration gradients across the disrupted tight junction barrier. This phenomenon leads to an increase in the concentrations of different proteins of blood origin such as lactoferrin, BSA, and Ig in mammary secretions during the first week of involution (Nonnecke and Smith, 1984; Sordillo et al., 1987). During lactation, BSA is almost absent in milk. After drying-off, the BSA concentration increases until d 14 (Tremblay et al., 2009; Ollier et al., 2013) and remains high throughout the dry period (Nonnecke and Smith, 1984; Sordillo et al., 1987). In a similar way, the concentration of lactoferrin in milk is low during lactation and increases abruptly during the first 2 wk of involution before declining thereafter (Nonnecke and Smith, 1984; Ollier et al., 2013). The content of IgG in mammary secretions also increases progressively during the first days of the dry period (Nonnecke and Smith, 1984; Sordillo et al., 1987). Moreover, lactose and $\alpha$-LA decrease in milk and concurrently increase in blood during milk stasis (Sordillo et al., 1987; Stelwagen et al., 1994). In addition, the ionic composition of milk is altered as the gland enters the involution process. In particular, the concentration of potassium in milk decreases, whereas that of sodium increases after drying-off (Ollier et al., 2013). All of these modifications are facilitated by the elevated tight junction permeability during involution and constitute good indicators for measuring the extent of the involution process. Another change in mammary secretion composition is the reduction of milk citrate concentrations after cessation of milking. Although citrate content is relatively high during lactation, which is indicative of the level of activity of mammary epithelial cells, it decreases during at least the first $2 \mathrm{wk}$ of involution (Nonnecke and Smith, 1984; Sordillo et al., 1987; Ollier et al., 2013). The citrate:lactoferrin ratio can be calculated to give an indication of the extent of the involution process. During lactation, this ratio is high, whereas it declines progressively during the first week of involution and remains low throughout the dry period (Nonnecke and Smith, 1984; Sordillo et al., 1987; Ollier et al., 2013). The changes in all of these parameters induced by the impairment of tight junction integrity make them good markers to measure mammary gland involution rate.

\section{Mammary Gland Involution Solicits Elements of the Immune System}

Another characteristic of active involution is recruitment of immune cells. Overall, the total number of leukocytes increases rapidly in bovine milk during the first $3 \mathrm{~d}$ of involution and remains elevated until calving (Nonnecke and Smith, 1984; Hurley, 1989), and SCC increases in mammary secretions from the last milk removal to at least d 10 to 14 of involution (Sordillo et al., 1987; Ollier et al., 2013). During the early stages of involution, PMN are the predominant leukocytes in mammary secretions for the first 2 to $4 \mathrm{~d}$ after dryingoff (Sordillo et al., 1987; Tatarczuch et al., 2000). As involution progresses, macrophages replace PMN as the predominant immune cell type (Monks et al., 2002; Atabai et al., 2007). Neutrophils and macrophages are thought to play a role in the clearance of casein micelles, lipid droplets, and cellular debris (Monks et al., 2002; Atabai et al., 2007). This partially explains the high susceptibility of the mammary gland to infections during the early dry period because of interference from components in milk, especially the fat globules (Paape et al., 1979) and incapacitation of the phagocytic cells (Tatarczuch et al., 2002).

\section{Mammary Gland Involution Requires the Activation of Several Proteases}

Plasmin-Plasminogen-Plasminogen Activator System. Mammary gland involution also involves the activation of different proteases. Among those proteases, plasmin is a major enzyme responsible for the cleavage of different casein subtypes, leading to the formation of casein breakdown products. The majority of the peptidic fragments obtained by plasmin activity during bovine mammary gland involution come from $\beta-\mathrm{CN}$ degradation (Aslam and Hurley, 1998). Plasmin is a serine protease that is found in milk during lactation in its inactive form, plasminogen. Plasmin and plasminogen concentrations in milk increase as lactation advances, and they increase further during bovine mammary gland involution (Politis et al., 1989a, 1990; Aslam et al., 1994). During the dry period, the plasminogen: 
plasmin ratio is markedly decreased, which is indicative of a high conversion of plasminogen into active plasmin (Politis et al., 1990; Athie et al., 1997). The conversion of plasminogen into plasmin is regulated by other enzymatic agents, namely plasminogen activators (PA) and PA inhibitors (PAI). Both PA and PAI are produced by bovine mammary epithelial cells (Heegard et al., 1994). The balance between PA and PAI controls the activation of the plasminogen-plasmin-PA system. In cows, plasmin, plasminogen, and PA activities are greatly enhanced during mammary gland involution (Aslam and Hurley, 1997; Athie et al., 1997). Two forms of PA are found in the mammary gland: the tissue-type PA (tPA) and the urokinase-type PA (uPA; Heegaard et al., 1994). The tPA is associated with casein micelles and binds more specifically to $\alpha_{\mathrm{S2}^{-}}$and $\kappa$-CN, whereas the $\mathrm{uPA}$ is associated with milk somatic cells in bovines and binds to the uPA receptor (Heegaard et al., 1994; Ismail et al., 2006; Weng et al., 2006). The immune system also contributes to the activation of plasminogen, as uPA and uPA receptors are associated with PMN in cows (Chou et al., 2009).

During involution, levels of tPA and uPA increase sharply (Ossowski et al., 1979; Strange et al., 1992; Flint et al., 2006), thus stimulating the activation of plasmin. Once activated, plasmin degrades mainly $\alpha_{S^{-}}$ and $\beta-\mathrm{CN}$ but also $\kappa-\mathrm{CN}$ and lactoferrin (Aslam and Hurley, 1997; Politis et al., 1989b). $\alpha$-Lactalbumin and $\beta-\mathrm{LG}$ seem to be resistant to proteolysis (Aslam and Hurley, 1997). This action of plasmin on milk proteins contributes to the change in milk composition occurring during mammary gland involution.

Metalloproteinase System. Matrix metalloproteinases (MMP) constitute a family of proteases that play a major role in mammary gland involution. Specifically, these enzymes are involved in degradation of the extracellular matrix, the basement membrane, or both. Many of those proteases, such as MMP-1, MMP-2, MMP-14, and MMP-19, are upregulated during involution in cattle (Rabot et al., 2007). Within the MMP family, 3 enzymes [stromelysin 1 (MMP-3), gelatinase A (MMP-2), and gelatinase B (MMP-9)] have been intensively studied in relation to mammary gland involution. Stromelysin 1 is a metalloproteinase that is exclusively expressed in the mammary gland and particularly in myoepithelial cells. In cows, MMP-3 expression is increased during late lactation (De Vries et al., 2011). Boudreau et al. (1995) reported that the degradation of the basement membrane by MMP-3 caused a substantial increase in apoptosis both in vitro and in vivo. Gelatinase A (MMP-2) and MMP-9 are 2 other proteases that both have the property to de- grade the basement membrane collagens and that possess gelatinolytic activity (Matrisian, 1990). Produced mostly by myoepithelial cells, MMP-2 is also enhanced during bovine mammary gland involution (Miller et al., 2006; Tremblay et al., 2009). Some epithelial cells express MMP-2 and MMP-3 in the form of cytoplasmic granules (Dickson and Warburton, 1992). The levels of MMP-9 in mammary tissue are low during lactation and increase markedly during involution in both rodents and cows (Lund et al., 2000; Tremblay et al., 2009). Somatic cells are an important source of MMP-9 (Mehrzad et al., 2005), and its activity in milk is correlated with SCC (Miller et al., 2006). The activation of those MMP is regulated by the tissue inhibitor of metalloproteinases (TIMP). Indeed, the ratio between MMP and TIMP decides the fate of the basement membrane and the extracellular matrix as well as the remodeling process of the mammary gland after drying-off. When the ratio of MMP to TIMP is low, degradation of the extracellular matrix is prevented and involution is slow (Talhouk et al., 1992). When the ratio is high, the extracellular matrix is degraded and mammary gland remodeling takes place. Thus, degradation of the extracellular matrix and basement membrane during involution is due to a shift in the balance between MMP and TIMP that favors a marked increase in MMP and, in turn, proteolysis.

Loss of Cell-Extracellular Matrix Communication Triggers Mammary Epithelial Cell Apoptosis. The proteolytic degradation of the extracellular matrix by MMP and the plasmin-plasminogen systems leads to a reduction in the communication between epithelial cells and the extracellular matrix. This loss of attachment to the basement membrane induces and accelerates apoptosis (Merto et al., 1997). The alveolar epithelial cells, which are responsible for milk production, interact with the laminin-rich basement membrane for their survival through integrins (Boudreau et al., 1995; Pullan et al., 1996; Farrelly et al., 1999). In bovine mammary glands, expressions of $\alpha 5-, \alpha 6-$, and 31 -integrin mRNA decreased after $24 \mathrm{~h}$ of milk accumulation relative to $6 \mathrm{~h}$ after milking (Singh et al., 2005). The disruption of the interaction between mammary epithelial cells and the extracellular matrix by the addition of an antibody directed against $\alpha 6-$ or $\beta 1$-integrins led to an increase in apoptosis (Boudreau et al., 1995; Pullan et al., 1996; Farrelly et al., 1999). Consequently, the downregulation of integrins in the bovine mammary tissue disrupts the communication between mammary epithelial cells and the extracellular matrix and participates in triggering apoptosis during involution. 
IGFBP-5 and STAT3 Are 2 Key Effectors of Mammary Gland Involution

IGF-IGF-Binding Protein System. The survival of mammary epithelial cells is driven and regulated coordinately by the basal membrane and by signals from insulin, IGF-1, and IGF-2 (Farrelly et al., 1999). In the bovine mammary gland, IGF-1 is upregulated during involution, and that upregulation is associated with periods of high cell turnover. Indeed, expression of IGF$1 \mathrm{mRNA}$ is highest during mammogenesis, decreases during lactogenesis and galactopoiesis, and increases during involution (Plath-Gabler et al., 2001; Sorensen et al., 2006). Conversely, expression of IGF-2 mRNA, although relatively high during mammogenesis and lactation, decreases after drying-off (Plath-Gabler et al., 2001). The mammary tissue is also more sensitive to IGF-1, as expression of the IGF-1 receptor is increased after drying-off in cows (Plath-Gabler et al., 2001). During the dry period itself, IGF-1 mRNA expression does not vary significantly (Wall et al., 2005). Nonetheless, it seems that IGF-1, given its role in stimulating cell proliferation, is involved in mammary epithelial cell renewal during involution.

The effect of IGF-1 is regulated by IGF-binding proteins (IGFBP). Expression of IGFBP-5 is upregulated during the first $2 \mathrm{wk}$ of involution in cows (Sorensen et al., 2006). The IGFBP-5 protein promotes mammary epithelial cell apoptosis (Tonner et al., 2002; Flint et al., 2006), likely by inhibiting the survival signal driven by IGF-1 (Marshman et al., 2003). As well, IGFBP-5 activates the proteolytic degradation of the mammary epithelium (Tonner et al., 2002) and can interact with the plasmin-plasminogen system. It has been shown that IGFBP-5, probably by binding PAI-1 (Nam et al., 1997), counteracts the inhibitory effect of PAI-1 on plasminogen activation by stimulating tPA (Sorrell et al., 2006). Therefore, the IGF-IGFBP system is implicated in the regulation of mammary gland involution, and IGFBP- 5 seems to be a key mediator in the occurrence of this process.

Janus Kinase-Signal Transducer and Activator of Transcription Signaling Pathway. Another feature of mammary gland involution is modified expression of the signal transducer and activator of transcription (STAT) factors. After their activation by phosphorylation and dimerization, STAT can induce the transcription of genes involved in cell proliferation through the activation of the Janus kinase (JAK)STAT pathway. Two members of the STAT family change significantly during mammary gland involution: STAT5, with its subtypes STAT5a and STAT5b, and STAT3. Specifically, after weaning or cessation of milk- ing, STAT5 is downregulated, whereas STAT3 is upregulated. The STAT5 factor is involved in cell division and differentiation, favors cell-cell adhesion (Miyoshi et al., 2001), and is inversely related to apoptosis. It was shown that overexpression of STAT5 in mice accelerated mammary development during pregnancy, enhanced mammary cell differentiation, stimulated mammary epithelial cell proliferation, and delayed mammary gland involution (Iavnilovitch et al., 2002). During lactation, concentrations of STAT5 and its phosphorylated, activated form, phospho-STAT5, are high, but after cessation of milking, both concentrations decline as early as d 2 of involution (Flint et al., 2006). The abundance and phosphorylation of STAT5a are both markedly reduced during involution, leading to a decrease in the phospho-STAT5a:STAT5a ratio in mice (Chapman et al., 1999; Bertucci et al., 2010). Mammary epithelial cells are therefore deprived of a proliferative signal during that time. In the mammary gland, the binding of prolactin (PRL) to its receptor (long isoform) induces the phosphorylation of STAT5a and STAT5b (Hennighausen et al., 1997). With cessation of milking, not only is the milking-induced PRL release abolished, the basal PRL concentration is also reduced (Bernier-Dodier et al., 2011). In cows, PRL inhibition decreases proliferation and increases apoptosis of mammary epithelial cells (Boutinaud et al., 2012), suggesting that STAT5, activated by PRL, is a surviving factor for these cells.

Contrary to STAT5, STAT3 is highly associated with involution and apoptosis. For instance, in mice with a conditional knockout of STAT3, involution was delayed and apoptosis of mammary epithelial cells was inhibited (Chapman et al., 1999). The prevention of milk removal activates STAT3, inhibits STAT5a and STAT5b phosphorylation and heterodimerization, and locally induces apoptosis of alveolar cells ( $\mathrm{Li}$ et al., 1997). In mice, STAT3 is barely detectable during lactation, but by d 2 of involution, STAT3 concentration and phosphorylation are markedly upregulated, leading to an increase in the phospho-STAT3:STAT3 ratio (Chapman et al., 1999; Flint et al., 2006; Bertucci et al., 2010). Last, STAT3 also appears to stimulate IGFBP-5 expression (Chapman et al., 1999).

\section{ACCELERATING MAMMARY GLAND INVOLUTION}

\section{Is There a Need to Accelerate Mammary Gland Involution?}

Although the dry period is important for optimal milk production in the subsequent lactation, the cow is highly susceptible to new IMI during the first $3 \mathrm{wk}$ of 
the dry period (Eberhart, 1986). With increasing milk production, drying-off has become a challenging period for dairy cows. Milk is no longer removed, but the mammary gland temporarily continues to synthesize milk, which is an excellent medium for bacterial growth. Thus, milk accumulation and leakage via the teats can occur, facilitating the entry of microorganisms into the mammary gland (Oliver and Sordillo, 1989). The risk of acquiring a new infection during the dry period therefore increases rapidly with the level of milk production at the time of drying-off (Rajala-Schultz et al., 2005; Newman et al., 2010). Once mammary gland involution is completed, within $30 \mathrm{~d}$ after cessation of milking, the mammary gland becomes much more resistant to new IMI because of a low fluid volume in the udder and a medium unfavorable for bacterial growth (Breau and Oliver, 1986). Accordingly, Nonnecke and Smith (1984) reported that inhibition of Escherichia coli growth by milk whey increased significantly during the dry period and that maximum inhibition was obtained with milk whey collected on d 15 of the dry period. As it is now common to dry off cows that are still producing more than $25 \mathrm{~kg}$ of milk/d, it is important to develop strategies that reduce milk production before drying-off and to hasten mammary gland involution.

A 60-d dry period has been routinely recommended and practiced for many years. However, there is now interest in re-evaluating the optimal length of the dry period because a short dry period has several advantages over a conventional dry period of 55 to 70 d. First, a short dry period extends the lactation before dryingoff, thus giving additional milk. In addition, because it allows the cow to reach a lower milk yield before the cessation of milking, a short dry period could be beneficial for mammary gland health. Moreover, a short dry period allows a reduction in the number of dietary changes during the dry period, which could facilitate ruminal adaptation during the transition period and reduce the incidence of postpartum disorders (Bachman and Schairer, 2003). However, decreasing the dry period length to less than $40 \mathrm{~d}$ has frequently been reported to reduce milk yield during the subsequent lactation (Gulay et al., 2005; Church et al., 2008; Pezeshki et al., 2008; Watters et al., 2008; Bernier-Dodier et al., 2011), thus offsetting the potential benefits of shortening the dry period. The decrease in milk secretion during the subsequent lactation following a shorter dry period could be due to reduced mammary epithelial cell activities, reduced numbers of epithelial cells, or both phenomena. Both whole-animal and half-udder model studies showed that the proliferation of mammary epithelial cells was greatly depressed before parturition in the absence of a dry period (Capuco et al., 1997; Annen et al., 2007). Mammary epithelial cell apoptosis was also decreased by $60 \%$ after parturition in continuously milked glands compared with mammary glands in dry periods (Annen et al., 2007). Hence, in the complete absence of a dry period, mammary epithelial cell turnover is reduced and the replacement of senescent cells is compromised compared with a regular 60-d dry period. Moreover, this means that there are more senescent or nonfunctional secretory cells at the beginning of the next lactation, which may be a causative factor for reduced milk production in continuously milked cows in the following lactation. It is thus necessary to allow the mammary gland to complete its involution and to optimize renewal of the epithelial cell population. In this regard, accelerating involution would be beneficial by enabling shorter dry periods without having a negative effect on the following lactation.

\section{Systemic Strategies to Accelerate Mammary Gland Involution}

Effects of Nutrient Restriction on Mammary Gland Involution. A common drying-off practice among farmers involves a drastic short-term reduction in feed supply in the days that precede the drying-off. Although this method is effective for rapidly reducing milk yield, little attention has been given to the effect of this practice on mammary gland involution. Although explicit evidence of a direct relationship between milk production level and the rate of involution is lacking, it is reasonable to assume that such a relationship exists. Accordingly, Bushe and Oliver (1987) reported that mammary secretions from cows milked intermittently and fed only hay contained higher concentrations of somatic cells, lactoferrin, IgG, and BSA, had a lower citrate:lactoferrin molar ratio, and were more inhibitory to in vitro growth of $E$. coli than were mammary secretions from cows dried off by intermittent or abrupt milk cessation and fed a TMR. Ollier et al. (2014) fed cows only dry hay during the last $5 \mathrm{~d}$ before drying-off and reported a decrease in milk production and BSA concentration, a faster increase in the $\mathrm{Na}^{+}: \mathrm{K}^{+}$ratio, and a faster decrease in the citrate:lactoferrin ratio in the mammary secretions of those cows than in the secretions of control cows, indicating a faster rate of involution. On the other hand, another study by Ollier et al. (2014) showed that a reduction in nutrient supply at drying-off led to metabolic disturbance, including an increase in plasma nonesterified fatty acid concentrations comparable with the increase that was observed in early lactation (Loiselle et al., 2009). In addition, Ster et al. (2012) showed that immune functions such as lymphocyte multiplication and cytokine release were 
inhibited by serum obtained from periparturient cows and that this inhibition was directly related to nonesterified fatty acid concentrations in the serum. Accordingly, Ollier et al. (2014) observed that the serum harvested from hay-fed cows on the day before dryingoff reduced peripheral blood mononuclear cell proliferation and IL-4 production. It is therefore possible that part of the gain in disease resistance obtained by reducing milk production at drying-off by means of feed restriction would disappear owing to immunosuppression. In a subsequent experiment, Ollier et al. (2015) used a bacterial challenge to test whether feeding dry hay to cows for the last $5 \mathrm{~d}$ of lactation could affect their susceptibility to new IMI. The cows were challenged by daily teat dipping in a solution containing Streptococcus agalactiae at $5 \times 10^{7} \mathrm{cfu} / \mathrm{mL}$. No differences between the dry hay group and the control group were observed for either bacterial count or infection rate.

Injections of Estradiol to Accelerate Mammary Gland Involution. Several studies have identified estrogens as a possible factor for the decline in milk production after the peak of lactation. For instance, Bachman et al. (1988) reported that the decline in milk yield began at about $100 \mathrm{~d}$ of gestation, which coincides with the onset of estrogen secretion by the fetal-placental unit. Lactation records for Holstein and Jersey herds from the United States show that pregnancy depresses yield, particularly in the last third of lactation (Bormann et al., 2002). A more recent study has shown that ovariectomy improves lactation persistency (Yart et al., 2012). The administration of $17 \beta$-estradiol (E2) to lactating cows causes mammary gland regression and a decrease in milk production (Mollett et al., 1976; Delbecchi et al., 2005). These results indicate a role for estrogens in the regulation of bovine mammary gland involution and thus suggest that the injection of estrogens at drying-off might accelerate involution.

To evaluate whether estrogens induce mammary gland involution, large doses $(15 \mathrm{mg} / \mathrm{d})$ of $\mathrm{E} 2$ were given on the last $4 \mathrm{~d}$ before cessation of milking (Athie et al., 1996). The E2 injections induced a rapid decline in milk production before drying-off as well as the hastening of milk composition changes after drying-off, suggesting the acceleration of involution. In addition, the same authors reported that there was activation of the plasmin-plasminogen system (Athie et al., 1996). Nevertheless, subsequent studies did not detect any beneficial effects of supplemental estrogen on subsequent milk yield when the estrogen was provided at the start of dry periods shortened to $30 \mathrm{~d}$ (Bachman, 2002; Gulay et al., 2003). Furthermore, an analysis of the temporal profiles of lactose in the blood plasma of cows supplemented with E2 did not indicate a hastening of tight junction leakage (Gulay et al., 2009).
PRL Inhibition as a Tool to Accelerate Mammary Gland Involution. Although the role of PRL in dairy ruminants has been controversial for many years, recent studies have provided several lines of evidence that PRL is galactopoietic in ruminant lactation (for a review, see Lacasse et al., 2016). Using the dopamine agonist quinagolide to inhibit PRL release reduced milk production in cows (Lacasse et al., 2011). In addition, cell proliferation was lower and apoptosis was greater in the mammary tissue of quinagolide-treated cows, suggesting that cell turnover and involution rate were affected (Boutinaud et al., 2012). The inhibition of mammary epithelial cell loss by PRL is further supported by the fact that PRL deficiency induced involution of the rat mammary gland by increasing apoptosis and decreasing the DNA content of the gland, an effect that was prevented by PRL administration (Travers et al., 1996). Moreover, PRL injections significantly reduced the dramatic increase in IGFBP-5 observed during mammary gland involution (Tonner et al., 1997). Accorsi et al. (2002) reported that bovine mammary explants cultured in a medium containing no PRL displayed significant increases in DNA laddering, which is characteristic of cellular apoptosis, and in IGFBP-5 mRNA expression compared with mammary explants cultured in a medium containing PRL, growth hormone, insulin, IGF-1, hydrocortisone, E2, and progesterone. Prolactin is also able to counteract the increase in proteolytic activity observed during mammary gland involution. In rodents, the increase in plasmin and PA activities triggered by unilateral teat sealing or litter removal was inhibited by PRL (Tonner et al., 2000). It has been suggested that PRL enhances PAI-1 release by inhibiting IGFBP-5 synthesis, thus leading to tPA inactivation (Fattal et al., 1992; Tonner et al., 2000). Moreover, the decreases in mammary gland weight and DNA content and the increase in PA concentration that are naturally observed during involution were all reduced by injections of PRL in mice (Ossowski et al., 1979). Taken together, these results suggest that PRL inhibition could be used as a management tool to facilitate drying-off.

In a first study by Ollier et al. (2013), late-lactation cows were injected twice daily with quinagolide $(2 \mathrm{mg} /$ injection) from $4 \mathrm{~d}$ before drying-off until $3 \mathrm{~d}$ after. The quinagolide injections reduced milk production at drying-off by $20 \%$ and increased SCC and BSA concentrations in milk during early involution, suggesting that involution was hastened. In a subsequent experiment by Ollier et al. (2014), a larger dose of quinagolide (4 mg) was injected twice daily from $5 \mathrm{~d}$ before drying-off until $13 \mathrm{~d}$ after. Again, the quinagolide injections inhibited milk production before drying-off. The mammary gland involution rate was markedly accelerated, as the 
quinagolide treatment hastened the normal changes in several involution markers such as SCC, BSA, citrate: lactoferrin molar ratio, $\mathrm{Na}^{+}: \mathrm{K}^{+}$ratio, and MMP-2 activity. In a third study, Ollier et al. (2015) repeated the same treatments on another group of cows, some of which were also challenged with $S$. agalactiae. Both the number of $S$. agalactiae colonies found in mammary secretions and the percentage of $S$. agalactiae-infected quarters on $\mathrm{d} 8$ and 14 after the last milking were lower in the quinagolide-treated cows than in the control cows.

Cabergoline, another dopamine agonist, has been used to facilitate drying-off in cows. Instead of multiple injections, a single injection of cabergoline was administered just after the last milking before dryingoff. Milk leakage, udder pressure, and udder firmness were reduced by cabergoline, indicating a reduction in milk synthesis (Bach et al., 2015; Bertulat et al., 2017). Furthermore, cabergoline enhanced extracellular matrix remodeling in the mammary gland and the exfoliation of mammary epithelial cells into milk and also accelerated the changes in the composition of mammary secretions, indicating the hastening of mammary gland involution (Boutinaud et al., 2016, 2017).

Based on results obtained from various studies, Velactis, a cabergoline-based product, was commercialized in Europe and several Latin American countries. However, as some cows were reported to suffer from symptoms similar to periparturient hypocalcemia, Velactis was withdrawn from the European market. Given that PRL is known to play a role in calcium homeostasis in fish (Flik et al., 1994) and that calcium absorption in rats was depressed by another dopamine agonist, bromocriptine (James et al., 1977), it is possible that the inhibition of PRL might cause hypocalcemia. However, calcemia was higher during the first week of lactation in cows treated with quinagolide (Vanacker et al., 2017). In addition, no significant change in calcemia was observed in another study despite the change in blood PRL concentration by about 30-fold during the course of the experiment (P. Lacasse, X. Zhao, and N. Vanacker, Université de Sherbrooke, Canada, and M. Boutinaud, INRA, Rennes, France, unpublished data). These suggest that the effect of Velactis on calcium homeostasis may be independent of the product's effect on PRL concentrations.

Modulation of Photoperiods to Accelerate the Involution Process. A well-known environmental condition that affects PRL secretion is the photoperiod. The photoperiod corresponds to the daily alternation between episodes of light, the photophase, and episodes of darkness, the scotophase. Generally, blood PRL concentrations are higher in bovines exposed to long-day photoperiods (LDPP) than in bovines exposed to short-day photoperiods (SDPP; Dahl and Petitclerc, 2003). Accordingly, dry cows exposed to LDPP displayed greater plasma PRL concentrations (Miller et al., 2000; Auchtung et al., 2005; Velasco et al., 2008; Lacasse et al., 2014) and a greater periparturient PRL surge (Newbold et al., 1991; Auchtung et al., 2004; Lacasse et al., 2014) than dry cows exposed to SDPP. Blood PRL concentrations were also higher in primiparous heifers exposed to LDPP than in those exposed to SDPP (Peters and Tucker, 1978; Lacasse et al., 2014). Therefore, the photoperiod is a natural way to manipulate PRL secretion.

A change in the photoperiod, occurring either during lactation or during the dry period, exerts a marked effect on milk synthesis. Generally, dairy animals exposed during lactation to LDPP produce more milk than those exposed to SDPP. The photoperiod can also be modified during the dry period. In that case, the effects of photoperiod manipulation are opposite those that occur during lactation. Indeed, cows exposed to LDPP during the dry period produced less milk during the following early lactation than cows exposed to SDPP (Miller et al., 2000; Auchtung et al., 2005; Velasco et al., 2008; Lacasse et al., 2014). Therefore, exposing cows to SDPP during the dry period is an interesting way to increase milk production during the following lactation, and this technique can be used in combination with a shortened dry period. It was shown in Holstein cows that SDPP applied during a short dry period of $42 \mathrm{~d}$ improved milk production during the subsequent lactation compared with LDPP (Velasco et al., 2008).

Besides PRL, melatonin is another hormone that is closely associated with the photoperiod. Melatonin is released by the pineal gland (Stanisiewski et al., 1988), and its secretion displays a circadian profile and a pulsatile secretory pattern (Critser et al., 1987). In the cow, melatonin concentrations in blood are high during the night and low during daylight (Lacasse et al., 2014). Because the duration of melatonin release is correlated with the duration of darkness, it has been suggested that the duration of the melatonin surge drives photoperiodic information in cattle (Buchanan et al., 1992). Thus, more melatonin is secreted during SDPP. Melatonin can therefore be administered to ruminants to mimic the effects of SDPP exposure. In dairy cows, subcutaneous implants of melatonin reduced plasma PRL concentrations by wk 4 of treatment and decreased milk production by wk 6 , an effect that was sustained until the end of the experiment (Auldist et al., 2007). Melatonin administration induced changes in milk composition that resembled 
those that occur during late lactation as cows approach involution.

Recently, Ponchon et al. (2017) assessed whether an SDPP or the oral administration of melatonin around drying-off would hasten mammary gland involution. From $14 \mathrm{~d}$ before to $14 \mathrm{~d}$ after drying-off, cows in late lactation were exposed to an SDPP, an LDPP alone, or an LDPP with supplementation by melatonin feeding $(4 \mathrm{mg} / \mathrm{kg}$ of BW). The SDPP slightly decreased milk production at drying-off and basal PRL secretion during the dry period, but these parameters were not affected by melatonin supplementation. None of the involution markers were affected by the treatments, suggesting that photoperiod modulation and melatonin feeding are not efficient means to accelerate mammary gland involution.

\section{Mammary Gland-Focused Strategies to Accelerate Mammary Gland Involution}

Intramammary Infusions of Substances that Increase Tight Junction Permeability. One approach to accelerate involution is to administer, through the teat canal, treatments that are known to increase tight junction permeability in the mammary gland. As tight junctions are more permeable during involution, these treatments could affect the involution process. Different treatments have been infused into the mammary glands of dairy goats or cows to affect tight junction integrity.

The activation of the plasminogen-plasmin-PA system during mammary gland involution leads to degradation of the $\alpha_{\mathrm{S1}^{-}}, \alpha_{\mathrm{S}^{-}}$, and $\beta$-CN. It has been proposed that casein breakdown products could constitute a signal for mammary epithelial cells to stop milk synthesis. A research team from Israel tried to mimic the accumulation of casein breakdown products during milk stasis by administration of casein hydrolysates (CNH) into the mammary gland. Shamay et al. (2002) showed that the intramammary infusion into the goat udder of fragments of caseins hydrolyzed by trypsin led to a decrease in milk production. In the treated gland, CNH infusions enhanced plasmin and PA concentrations and caused an increase in sodium and BSA concentrations as well as a decrease in potassium and lactose concentrations in milk, which are characteristic of an increase in tight junction permeability (Shamay et al., 2002).

In late-lactation Holstein cows, intramammary infusions of $\mathrm{CNH}$ reduced mammary gland secretions and mimicked the changes that occur in milk during the cessation of milking at drying-off (Shamay et al., 2003). The CNH treatment affected mammary tight junction integrity and led, notably, to an increase in lactoferrin concentration, another characteristic of mammary gland involution (Shamay et al., 2003). More recently, Ponchon et al. (2014) reported that the mammary secretions of dairy cow quarters infused with $\mathrm{CNH}$ showed a faster increase in SCC, BSA, $\mathrm{Na}^{+}$, and lactoferrin concentrations, suggesting the hastening of mammary gland involution. Nevertheless, when CNHtreated quarters were challenged with $S$. agalactiae as described in Ollier et al. (2015), no protection was observed [S. Ollier (AAFC, Sherbrooke R\&D Centre, Canada), X. Zhao, and P. Lacasse, unpublished data].

To maintain integrity of the mammary epithelial cells' tight junctions, the extracellular concentration of calcium needs to be kept at a certain level (Pitelka et al., 1983). The compound EGTA is a chelator of calcium and induces the disruption of tight junctions in mammary epithelial cells in lactating goats. The administration of a solution of $68 \mathrm{~m} M$ EGTA (final concentration infused into the mammary gland) led to increases in sodium and chloride concentrations in milk as well as increases in potassium and lactose concentrations in blood, suggesting that the permeability of tight junctions was compromised (Stelwagen et al., 1995). The EGTA treatment also caused an increase in milk protein percentage, possibly owing to the passage of blood proteins such as serum albumin into milk (Stelwagen et al., 1995). Moreover, the EGTA treatment was effective in decreasing milk production (Stelwagen et al., 1995). Ponchon et al. (2014) injected cows with $5.7 \mathrm{~g}$ of EGTA per quarter at drying-off. The EGTA infusion increased SCC above that of the control quarters only on the first $3 \mathrm{~d}$ following drying-off but had no effect on any of the involution markers.

Lactose is a milk-specific component and the main osmotic molecule in milk. In an experiment with dairy goats, Ben Chedly et al. (2010) observed that intramammary infusions of lactose solution via the teat canal led to an increase in the milk $\mathrm{Na}^{+}: \mathrm{K}^{+}$ratio and a tendency toward an increase in milk BSA concentration. Those authors also observed that isolated mammary epithelial cells from milk treated with a solution of $120 \mathrm{~m} M$ lactose showed a decrease in transepithelial electrical resistance (Ben Chedly et al., 2010), similar to what was found with the EGTA treatment in vitro (Rothen-Rutishauser et al., 2002). However, the infusion of $5.1 \mathrm{~g}$ of lactose into the quarters of late-lactation cows did not have any effects on the involution markers (Ponchon et al., 2014).

Intramammary Infusions of Substances that Stimulate the Immune System. Another approach to accelerate involution is to administer, through the teat canal, treatments that induce the recruitment of 
somatic cells in the mammary gland. As mentioned previously, immune cells play a role during involution. Accelerating their rise could not only help protect the gland against new infections but also accelerate the involution process. Nickerson et al. (1992), Oliver and Smith (1982), and Dallard et al. (2010) tested the effects of a single LPS infusion at drying-off. These studies reported an enhanced immune response and slightly accelerated involution in quarters infused with LPS. Although their experiments were not designed to test resistance to new IMI, Oliver and Smith (1982) and Dallard et al. (2007) reported a reduction in the number of mastitis pathogens isolated in the first weeks of the involution period in quarters treated with LPS. As was the case with LPS, the intramammary infusion of concanavalin A (Breau and Oliver, 1985), phytohemagglutinin (Breau and Oliver, 1985), or Panax ginseng extract (Baravalle et al., 2011) at drying-off activated the immune response. In addition, changes in the involution markers suggest faster involution in quarters treated with these substances (Bushe and Oliver, 1987; Dallard et al., 2011). The drawbacks of the biological response modifiers (defined as substances that modify immune responses) tested so far are that they induce acute inflammation of the entire mammary gland and that the stimulation of the immune system lasts for only a short period of time.

Ideally, a biological response modifier should induce moderate recruitment of immune cells without acute inflammation, and the immunostimulation should last for the whole period of active involution. In addition, the biological response modifier should not be eliminated if milk leakage occurs in the days following drying-off. Chitosan is a natural, biocompatible polysaccharide extracted from crustacean shells and the cell walls of fungi (Ruel-Gariépy and Leroux, 2004). Chitosan is water soluble, but gelation occurs at high concentrations, and the process is $\mathrm{pH}$ and temperature dependent (Cho et al., 2005). As a result, a chitosan solution can be formulated to be injected at room temperature but form a hydrogel at body temperature (Han et al., 2004; Taherian et al., 2017). The chitosan hydrogel is biodegradable by enzymes present in milk, so that the hydrogel's content is released over several days (Han et al., 2004). Chitosan exhibits various biological properties, including immunostimulating properties (Otterlei et al., 1994; Wen et al., 2011). Infusions of chitosan hydrogel at drying-off hastened the increases in SCC, BSA, and lactoferrin concentrations as well as lactate dehydrogenase activity in mammary secretions (Lanctôt et al., 2017). These results suggest that chitosan hydrogel infusion hastens mammary gland involution and activates an immune response, which may reduce the animal's risk of acquiring new IMI during the dry period. In addition, the effects of chitosan infusion were not affected by the presence of a teat sealant, showing that both approaches are fully compatible and could be used in combination (Lanctôt et al., 2017).

Effect of Milking Management Strategies on Mammary Gland Involution. Another method commonly used to reduce milk production at drying-off is intermittent milking. This easy method is effective in reducing milk production, but its effect on IMI at calving has not been clearly proven (Dingwell et al., 2003). As far as we know, only 1 study has examined the effect of this strategy on mammary gland involution. Bushe and Oliver (1987) milked cows once a day for $1 \mathrm{wk}$ and then did not milk them on the day before drying-off. Even though milk production at drying-off was reduced by $26 \%$, none of the involution markers evaluated were modified, suggesting that involution was not hastened (Bushe and Oliver, 1987).

Robotic milking, also known as automated or automatic milking, offers new opportunities for manipulating milking management. Martin et al. (2018) milked cows partially during the last $10 \mathrm{~d}$ of lactation using a software program that removed the cluster before the milking was complete. The amount of milk required before cluster removal was decreased daily. Milk production at drying-off was reduced by about $30 \%$. Although no classic indicators of involution were measured after drying-off, the milk concentration of haptoglobin, an acute-phase protein known to increase in mammary secretions after drying-off, at the last milking was elevated in partially milked cows (Martin et al., 2018). Although this research is very preliminary, the robotic milking approach may provide an opportunity to accelerate mammary gland involution.

\section{CONCLUSIONS}

The involution of the mammary gland after cessation of milking is a complex process that involves changes in mammary tissue morphology, secretion composition, and tight junction integrity. Although we know that immune cells, several types of proteases, and various types of hormones play important roles in involution, more research is needed to fully understand the mechanisms that underlie this process. Nevertheless, it can be concluded that approaches that reduce milk production at the time of drying-off accelerate mammary gland involution. In that respect, PRL inhibition and partial milking are the most promising approaches because they do not induce metabolic perturbations. The intramammary infusion of substances that increase mammary gland permeability hastens the initiation 
of involution. Further, the intramammary infusion of substances, such as chitosan hydrogel, that moderately stimulate the immune system for several days is also a promising approach to accelerate mammary gland involution.

\section{ACKNOWLEDGMENTS}

The authors thank Séverine Ollier (AAFC, Sherbrooke R\&D Centre, Canada) for her outstanding contribution to several of the research studies presented in this review. The authors are grateful to Mary Varcoe, from the Translation Bureau, Public Services and Procurement Canada, for her careful editing of this manuscript.

\section{REFERENCES}

Accorsi, P. A., B. Pacioni, C. Pezzi, M. Forni, D. J. Flint, and E. Seren. 2002. Role of prolactin, growth hormone and insulin-like growth factor 1 in mammary gland involution in the dairy cow. J. Dairy Sci. 85:507-513.

Akers, R. M., W. E. Beal, T. B. McFadden, and A. V. Capuco. 1990. Morphometric analysis of involuting bovine mammary tissue after 21 or 42 days on non-suckling. J. Anim. Sci. 68:3604-3613.

Annen, E. L., A. C. Fitzgerald, P. C. Gentry, M. A. McGuire, A. V. Capuco, L. H. Baumgard, and R. J. Collier. 2007. Effect of continuous milking and bovine somatotropin supplementation on mammary epithelial cell turnover. J. Dairy Sci. 90:165-183.

Aslam, M., and W. L. Hurley. 1997. Proteolysis of milk proteins during involution of the bovine mammary gland. J. Dairy Sci. 80:20042010.

Aslam, M., and W. L. Hurley. 1998. Peptides generated from milk proteins in the bovine mammary gland during involution. J. Dairy Sci. 81:748-755.

Aslam, M., R. Jiménez-Flores, H. Y. Kim, and W. L. Hurley. 1994. Two-dimensional electrophoretic analysis of proteins of bovine mammary gland secretions collected during the dry period. J. Dairy Sci. 77:1529-1536.

Atabai, K., D. Sheppard, and Z. Werb. 2007. Roles of the innate immune system in mammary gland remodeling during involution. J. Mammary Gland Biol. Neoplasia 12:37-45.

Athie, F., K. C. Bachman, H. H. Head, M. J. Hayen, and C. J. Wilcox. 1996. Estrogen administered at final milk removal accelerates involution of bovine mammary gland. J. Dairy Sci. 79:220-226.

Athie, F., K. C. Bachman, H. H. Head, M. J. Hayen, and C. J. Wilcox. 1997. Milk plasmin during bovine mammary involution that has been accelerated by estrogen. J. Dairy Sci. 80:1561-1568.

Auchtung, T. L., A. G. Rius, P. E. Kendall, T. B. McFadden, and G. E. Dahl. 2005. Effects of photoperiod during the dry period on prolactin, prolactin receptor, and milk production of dairy cows. J. Dairy Sci. 88:121-127.

Auchtung, T. L., J. L. Salak-Johnson, D. E. Morin, C. C. Mallard, and G. E. Dahl. 2004. Effects of photoperiod during the dry period on cellular immune function of dairy cows. J. Dairy Sci. 87:3683-3689.

Auldist, M. J., S.-A. Turner, C. D. McMahon, and C. G. Prosser. 2007. Effects of melatonin on the yield and composition of milk from grazing dairy cows in New Zealand. J. Dairy Res. 74:52-57.

Bach, A., A. De-Prado, and A. Aris. 2015. Short communication: The effects of cabergoline administration at dry-off of lactating cows on udder engorgement, milk leakages, and lying behavior. J. Dairy Sci. 98:7097-7101.

Bachman, K. C. 2002. Milk production of dairy cows treated with estrogen at the onset of a short dry period. J. Dairy Sci. 85:797-803.
Bachman, K. C., M. J. Hayen, D. Morse, and C. J. Wilcox. 1988. Effect of pregnancy, milk vield, and somatic cell count on bovine milk fat hydrolysis. J. Dairy Sci. 71:925-931.

Bachman, K. C., and M. L. Schairer. 2003. Invited review: Bovine studies on optimal lengths of dry periods. J. Dairy Sci. 86:30273037.

Baravalle, C., B. E. Dallard, M. C. Cadoche, E. A. L. Pereyra, V. E. Neder, H. H. Ortega, and L. F. Calvinho. 2011. Proinflammatory cytokines and CD14 expression in mammary tissue of cows following intramammary inoculation of Panax ginseng at drying off. Vet. Immunol. Immunopathol. 144:52-60.

Ben Chedly, H., M. Boutinaud, P. Bernier-Dodier, P.-G. Marnet, and P. Lacasse. 2010. Disruption of cell junctions induces apoptosis and reduces synthetic activity in lactating goat mammary gland. J. Dairy Sci. 93:2938-2951.

Bernier-Dodier, P., C. L. Girard, B. G. Talbot, and P. Lacasse. 2011. Effect of dry period management on mammary gland function and its endocrine regulation in dairy cows. J. Dairy Sci. 94:4922-4936.

Bertucci, P. Y., A. Quaglino, A. G. Pozzi, E. C. Kordon, and A. Pecci. 2010. Glucocorticoid-induced impairment of mammary gland involution is associated with STAT5 and STAT3 signaling modulation. Endocrinology 151:5730-5740.

Bertulat, S., N. Isaka, A. de Prado, A. Lopez, T. Hetreau, and W. Heuwieser. 2017. Effect of a single injection of cabergoline at dry off on udder characteristics in high-yielding dairy cows. J. Dairy Sci. 100:3220-3232.

Bormann, J., G. R. Wiggans, T. Druet, and N. Gengler. 2002. Estimating effects of permanent environment, lactation stage, age, and pregnancy on test-day yield. J. Dairy Sci. 85:263.e1-263.e21.

Boudreau, N., C. J. Sympson, Z. Werb, and M. J. Bissell. 1995. Suppression of ICE and apoptosis in mammary epithelial cells by extracellular matrix. Science 267:891-893.

Boutinaud, M., N. Isaka, E. Gandemer, P. Lamberton, S. Wiart, A. I. De Prado Taranilla, L. M. Sordillo, and V. Lollivier. 2017. Inhibiting prolactin by cabergoline accelerates mammary gland remodeling during the early dry period in dairy cows. J. Dairy Sci. 100:9787-9798.

Boutinaud, M., N. Isaka, V. Lollivier, F. Dessauge, E. Gandemer, P. Lamberton, A. I. De Prado Taranilla, A. Deflandre, and L. M. Sordillo. 2016. Cabergoline inhibits prolactin secretion and accelerates involution in dairy cows after dry-off. J. Dairy Sci. 99:5707-5718.

Boutinaud, M., V. Lollivier, L. Finot, R. M. Bruckmaier, and P. Lacasse. 2012. Mammary cell activity and turnover in dairy cows treated with the prolactin-release inhibitor quinagolide and milked once daily. J. Dairy Sci. 95:177-187.

Breau, W. C., and S. P. Oliver. 1985. Accelerated bovine mammary involution induced by infusion of concanavalin A or phytohemagglutinin. Am. J. Vet. Res. 46:816-820.

Breau, W. C., and S. P. Oliver. 1986. Growth inhibition of environmental mastitis pathogens during physiologic transitions of the bovine mammary gland. Am. J. Vet. Res. 47:218-222.

Buchanan, B. A., L. T. Chapin, and H. A. Tucker. 1992. Prolonged suppression of serum concentrations of melatonin in prepubertal heifers. J. Pineal Res. 12:181-189.

Bushe, T., and S. P. Oliver. 1987. Natural protective factors in bovine mammary secretions following different methods of milk cessation. J. Dairy Sci. 70:696-704.

Capuco, A. V., and R. M. Akers. 1999. Mammary involution in dairy animals. J. Mammary Gland Biol. Neoplasia 4:137-144.

Capuco, A. V., R. M. Akers, and J. J. Smith. 1997. Mammary growth in Holstein cows during the dry period: Quantification of nucleic acids and histology. J. Dairy Sci. 80:477-487.

Capuco, A. V., S. Ellis, S. Hale, E. Long, R. Erdman, X. Zhao, and M. Paape. 2003. Lactation persistency: Insights from mammary cell proliferation studies. J. Anim. Sci. 81(Suppl. 3):18-31.

Capuco, A. V., M. Li, E. Long, S. Ren, K. S. Hruska, K. Schorr, and P. A. Furth. 2002. Concurrent pregnancy retards mammary involution: Effects on apoptosis and proliferation of the mammary epithelium after forced weaning of mice. Biol. Reprod. 66:1471-1476.

Castillo, V., X. Such, G. Caja, R. Casals, E. Albanell, and A. A. K. Salama. 2008. Effect of milking interval on milk secretion and 
mammary tight junction permeability in dairy ewes. J. Dairy Sci. 91:2610-2619.

Chapman, R. S., P. C. Lourenco, E. Tonner, D. J. Flint, S. Selbert, K. Takeda, S. Akira, A. R. Clarke, and C. J. Watson. 1999. Suppression of epithelial apoptosis and delayed mammary gland involution in mice with a conditional knockout of Stat3. Genes Dev. 13:2604-2616.

Chiba, T., S. Kimura, K. Takahashi, Y. Morimoto, A. Sanbe, H. Ueda, and K. Kudo. 2014. Serotonin suppresses $\beta$-casein expression via inhibition of the signal transducer and activator of transcription 5 (STAT5) protein phosphorylation in human mammary epithelial cells MCF-12A. Biol. Pharm. Bull. 37:1336-1340.

Cho, J., M.-C. Heuzey, A. Bégin, and P. J. Carreau. 2005. Physical gelation of chitosan in the presence of $\beta$-glycerophosphate: The effect of temperature. Biomacromolecules 6:3267-3275.

Chou, W. K., T. C. Yu, S. E. Chen, H. C. Peh, W. B. Liu, M. T. Chen, H. Nagahata, and C. J. Chang. 2009. TNFo-mediated plasminogen activation on neutrophils is involved in the high plasmin activity in mammary secretion of drying-off cows. J. Dairy Res. 76:459-468.

Church, G. T., L. K. Fox, C. T. Gaskins, D. D. Hancock, and J. M. Gay. 2008. The effect of a shortened dry period on intramammary infections during the subsequent lactation. J. Dairy Sci. 91:4219-4225.

Colitti, M., and M. Farinacci. 2009. Cell turnover and gene activities in sheep mammary glands prior to lambing to involution. Tissue Cell 41:326-333.

Collier, R. J., L. L. Hernandez, and N. D. Horseman. 2012. Serotonin as a homeostatic regulator of lactation. Domest. Anim. Endocrinol. 43:161-170.

Critser, J. K., T. M. Block, S. Folkman, and E. R. Hauser. 1987. Effect of photoperiod on LH, FSH, prolactin and melatonin patterns in ovariectomized prepubertal heifers. J. Reprod. Fertil. 81:29-39.

Dahl, G. E., and D. Petitclerc. 2003. Management of photoperiod in the dairy herd for improved production and health. J. Anim. Sci. 81(Suppl. 3):11-17.

Dallard, B. E., C. Baravalle, C. Andreotti, H. H. Ortega, V. Neder, and L. F. Calvinho. 2011. Intramammary inoculation of Panax ginseng extract in cows at drying off enhances early mammary involution. J. Dairy Res. 78:63-71.

Dallard, B. E., H. H. Ortega, I. A. Iguzquiza, N. R. Salvetti, O. A Quaino, and L. F. Calvinho. 2010. The effect of a single intramammary infusion of a biological response modifier in cows at drying off. Vet. Res. Commun. 34:519-532.

Dallard, B. E., V. Ruffino, S. Heffel, and L. F. Calvinho. 2007. Effect of a biological response modifier on expression of growth factors and cellular proliferation at drying off. J. Dairy Sci. 90:2229-2240.

De Vries, L. D., T. Casey, H. Dover, M. J. VandeHaar, and K. Plaut. 2011. Effects of transforming growth factor- $\beta$ on mammary remodeling during the dry period of dairy cows. J. Dairy Sci. 94:60366046 .

Delbecchi, L., N. Miller, C. Prud'homme, D. Petitclerc, G. F. Wagner, and P. Lacasse. 2005. 17ß-estradiol reduces milk synthesis and increases stanniocalcin gene expression in the mammary gland of lactating cows. Livest. Prod. Sci. 98:57-66.

Dickson, S. R., and M. J. Warburton. 1992. Enhanced synthesis of gelatinase and stromelysin by myoepithelial cells during involution of the rat mammary gland. J. Histochem. Cytochem. 40:697-703.

Dingwell, R. T., D. F. Kelton, and K. E. Leslie. 2003. Management of the dry cow in control of peripartum disease and mastitis. Vet. Clin. North Am. Food Anim. Pract. 19:235-265.

Eberhart, R. J. 1986. Management of dry cows to reduce mastitis. J. Dairy Sci. 69:1721-1732.

Farrelly, N., Y.-J. Lee, J. Oliver, C. Dive, and C. H. Streuli. 1999 Extracellular matrix regulates apoptosis in mammary epithelium through a control on insulin signaling. J. Cell Biol. 144:1337-1348.

Fattal, P. G., D. J. Schneider, B. E. Sobel, and J. J. Billadello. 1992 Post-transcriptional regulation of expression of plasminogen activator inhibitor type $1 \mathrm{mRNA}$ by insulin and insulin-like growth factor 1. J. Biol. Chem. 267:12412-12415.

Fleet, I. R., and M. Peaker. 1978. Mammary function and its control at the cessation of lactation in the goat. J. Physiol. 279:491-507.
Flik, G., F. Rentier-Delrue, and S. E. Wendelaar Bonga. 1994. Calcitropic effects of recombinant prolactins in Oreochromis mossambicus. Am. J. Physiol. 266:R1302-R1308.

Flint, D. J., M. Boutinaud, C. B. A. Whitelaw, G. J. Allan, and A. F. Kolb. 2006. Prolactin inhibits cell loss and decreases matrix metalloproteinase expression in the involuting mouse mammary gland but fails to prevent cell loss in the mammary glands of mice expressing IGFBP-5 as a mammary transgene. J. Mol. Endocrinol. $36: 435-448$.

Guenette, R. S., H. B. Corbeil, J. Léger, K. Wong, V. Mézl, M. Mooibroek, and M. Tenniswood. 1994. Induction of gene expression during involution of the lactating mammary gland of the rat. J. Mol. Endocrinol. 12:47-60.

Gulay, M. S., M. J. Hayen, K. C. Bachman, T. Belloso, M. Liboni, and H. H. Head. 2003. Milk production and feed intake of Holstein cows given short (30-d) or normal (60-d) dry periods. J. Dairy Sci. 86:2030-2038.

Gulay, M. S., M. J. Hayen, H. H. Head, and K. C. Bachman. 2009 Short communication: Effect of estrogen supplemented at dry-off on temporal changes in concentrations of lactose in blood plasma of Holstein cows. J. Dairy Sci. 92:3815-3818.

Gulay, M. S., M. J. Hayen, H. H. Head, C. J. Wilcox, and K. C. Bachman. 2005. Milk production from Holstein half udders after concurrent thirty- and seventy-day dry periods. J. Dairy Sci. 88:3953-3962

Han, H. D., D. E. Nam, D. H. Seo, T. W. Kim, B. C. Shin, and H. S. Choi. 2004. Preparation and biodegradation of thermosensitive chitosan hydrogel as a function of $\mathrm{pH}$ and temperature. Macromol. Res. 12:507-511.

Heegard, C. E., J. H. White, B. Zavizion, J. D. Turner, and I. Politis. 1994. Production of various forms of plasminogen activator and plasminogen activator inhibitor by cultured mammary epithelial cells. J. Dairy Sci. 77:2949-2958.

Heegaard, C. W., L. K. Rasmussen, and P. A. Andreasen. 1994. The plasminogen activation system in bovine milk: Differential localization of tissue-type plasminogen activator and urokinase in milk fractions is caused by binding to casein and urokinase receptor. Biochim. Biophys. Acta 1222:45-55.

Helminen, H. J., and J. L. E. Ericsson. 1970. Quantitation of lysosomal enzyme changes during enforced mammary gland involution. Exp. Cell Res. 60:419-426.

Helminen, H. J., J. L. E. Ericsson, and S. Orrenius. 1968. Studies on mammary gland involution: IV. Histochemical and biochemical observations on alterations in lysosomes and lysosomal enzymes. J. Ultrastruct. Res. 25:240-252.

Hennighausen, L., G. W. Robinson, K.-U. Wagner, and W. Liu. 1997. Prolactin signaling in mammary gland development. J. Biol. Chem. 272:7567-7569.

Hernandez, L. L. 2018. ADSA Foundation Scholar Award: A role for serotonin in lactation physiology - Where do we go from here? J. Dairy Sci. 101:5671-5678.

Hernandez, L. L., C. M. Stiening, J. B. Wheelock, L. H. Baumgard, A. M. Parkhurst, and R. J. Collier. 2008. Evaluation of serotonin as a feedback inhibitor of lactation in the bovine. J. Dairy Sci. 91:1834-1844

Holst, B. D., W. L. Hurley, and D. R. Nelson. 1987. Involution of the bovine mammary gland: Histological and ultrastructural changes. J. Dairy Sci. 70:935-944.

Horseman, N. D., and R. J. Collier. 2014. Serotonin: A local regulator in the mammary gland epithelium. Annu. Rev. Anim. Biosci $2: 353-374$.

Hurley, W. L. 1989. Mammary gland function during involution. J. Dairy Sci. 72:1637-1646.

Hurley, W. L., and J. J. Rejman. 1986. $\beta$-Lactoglobulin and $\alpha$-lactalbumin in mammary secretions during the dry period: Parallelism of concentration changes. J. Dairy Sci. 69:1642-1647.

Iavnilovitch, E., B. Groner, and I. Barash. 2002. Overexpression and forced activation of stat 5 in mammary gland of transgenic mice promotes cellular proliferation, enhances differentiation, and delays postlactational apoptosis. Mol. Cancer Res. 1:32-47. 
Ismail, B., L. H. Choi, L. M. Were, and S. S. Nielsen. 2006. Activity and nature of plasminogen activators associated with the casein micelle. J. Dairy Sci. 89:3285-3295.

James, M. F., A. M. Makeen, S. Foley, J. Stevens, and C. J. Robinson. 1977. Effects of prolactin and bromocriptine upon calcium and phosphorus absorption in lactating and non-lactating rats. J. Endocrinol. 75:53P-54P.

Lacasse, P., V. Lollivier, R. M. Bruckmaier, Y. R. Boisclair, G. F. Wagner, and M. Boutinaud. 2011. Effect of the prolactin-release inhibitor quinagolide on lactating dairy cows. J. Dairy Sci. 94:1302-1309.

Lacasse, P., S. Ollier, V. Lollivier, and M. Boutinaud. 2016. New insights into the importance of prolactin in dairy ruminants. J. Dairy Sci. 99:864-874.

Lacasse, P., C. M. Vinet, and D. Petitclerc. 2014. Effect of prepartum photoperiod and melatonin feeding on milk production and prolactin concentration in dairy heifers and cows. J. Dairy Sci. 97:3589-3598.

Lanctôt, S., P. Fustier, A. R. Taherian, B. Bisakowski, X. Zhao, and P. Lacasse. 2017. Effect of intramammary infusion of chitosan hydrogels at drying-off on bovine mammary gland involution. J. Dairy Sci. 100:2269-2281

Li, M., X. Liu, G. Robinson, U. Bar-Peled, K.-U. Wagner, W. S. Young, L. Hennighausen, and P. A. Furth. 1997. Mammary-derived signals activate programmed cell death during the first stage of mammary gland involution. Proc. Natl. Acad. Sci. USA 94:3425-3430.

Linzell, J. L., and M. Peaker. 1972. Day-to-day variations in milk composition in the goat and cow as a guide to the detection of subclinical mastitis. Br. Vet. J. 128:284-295.

Loiselle, M. C., C. Ster, B. G. Talbot, X. Zhao, G. F. Wagner, Y R. Boisclair, and P. Lacasse. 2009. Impact of postpartum milking frequency on the immune system and the blood metabolite concentration of dairy cows. J. Dairy Sci. 92:1900-1912.

Lund, L. R., S. F. Bjorn, M. D. Sternlicht, B. S. Nielsen, H. Solberg, P. A. Usher, R. Osterby, I. J. Christensen, R. W. Stephens, T. H. Bugge, K. Dano, and Z. Werb. 2000. Lactational competence and involution of the mouse mammary gland require plasminogen. Development 127:4481-4492.

Lund, L. R., J. Romer, N. Thomasset, H. Solberg, C. Pyke, M. J. Bissell, K. Dano, and Z. Werb. 1996. Two distinct phases of apoptosis in mammary gland involution: Proteinase-independent and -dependent pathways. Development 122:181-193.

Marshman, E., K. A. Green, D. J. Flint, A. White, C. H. Streuli, and M. Westwood. 2003. Insulin-like growth factor binding protein 5 and apoptosis in mammary epithelial cells. J. Cell Sci. 116:675682

Martin, L. M., W. Büscher, and U. Müller. 2018. Automated milk yield reduction before drying-off. Page 11 in the Book of Abstracts for International Workshop on the Biology of Lactation in Farm Animals, Dubrovnik, Croatia.

Matrisian, L. M. 1990. Metalloproteinases and their inhibitors in matrix remodeling. Trends Genet. 6:121-125.

Matsuda, M., T. Imaoka, A. J. Vomachka, G. A. Gudelsky, Z. Hou, M. Mistry, J. P. Bailey, K. M. Nieport, D. J. Walther, M. Bader, and N. D. Horseman. 2004. Serotonin regulates mammary gland development via an autocrine-paracrine loop. Dev. Cell 6:193-203.

Mehrzad, J., C. Desrosiers, K. Lauzon, G. Robitaille, X. Zhao, and P. Lacasse. 2005. Proteases involved in mammary tissue damage during endotoxin-induced mastitis in dairy cows. J. Dairy Sci. $88: 211-222$

Merto, G. R., N. Cella, and N. E. Hynes. 1997. Apoptosis is accompanied by changes in Bcl-2 and Bax expression, induced by loss of attachment, and inhibited by specific extracellular matrix proteins in mammary epithelial cells. Cell Growth Differ. 8:251-260.

Miller, A. R. E., R. A. Erdman, L. W. Douglass, and G. E. Dahl. 2000 Effects of photoperiodic manipulation during the dry period of dairy cows. J. Dairy Sci. 83:962-967.

Miller, N., L. Delbecchi, D. Petitclerc, G. F. Wagner, B. G. Talbot, and P. Lacasse. 2006. Effect of stage of lactation and parity on mammary gland cell renewal. J. Dairy Sci. 89:4669-4677.
Miyoshi, K., J. M. Shillingford, G. H. Smith, S. L. Grimm, K.-U. Wagner, T. Oka, J. M. Rosen, G. W. Robinson, and L. Hennighausen. 2001. Signal transducer and activator of transcription (Stat) 5 controls the proliferation and differentiation of mammary alveolar epithelium. J. Cell Biol. 155:531-542.

Mollett, T. A., R. E. Erb, E. L. Monk, and P. V. Malven. 1976. Changes in estrogen, progesterone, prolactin and lactation traits associated with injection of estradiol-17 $\beta$ and progesterone into lactating cows. J. Anim. Sci. 42:655-663.

Monks, J., F. J. Geske, L. Lehman, and V. A. Fadok. 2002. Do inflammatory cells participate in mammary gland involution? J. Mammary Gland Biol. Neoplasia 7:163-176.

Nam, T. J., W. Busby Jr., and D. R. Clemmons. 1997. Insulin-like growth factor binding protein- 5 binds to plasminogen activator inhibitor-I. Endocrinology 138:2972-2978.

Newbold, J. A., L. T. Chapin, S. A. Zinn, and H. A. Tucker. 1991. Effects of photoperiod on mammary development and concentration of hormones in serum of pregnant dairy heifers. J. Dairy Sci. 74:100-108.

Newman, K. A., P. J. Rajala-Schultz, F. J. DeGraves, and J. Lakritz. 2010. Association of milk yield and infection status at dry-off with intramammary infections at subsequent calving. J. Dairy Res. 77:99-106.

Nguyen, D.-A. D., and M. C. Neville. 1998. Tight junction regulation in the mammary gland. J. Mammary Gland Biol. Neoplasia 3:233-246.

Nickerson, S. C., R. M. Akers, and B. T. Weinland. 1982. Cytoplasmic organization and quantitation of microtubules in bovine mammary epithelial cells during lactation and involution. Cell Tissue Res. 223:421-430.

Nickerson, S. C., W. E. Owens, R. L. Boddie, and N. T. Boddie. 1992 The effect of chronic immunostimulation of the nonlactating bovine mammary gland with interleukin-2, pokeweed mitogen, and lipopolysaccharide. J. Dairy Sci. 75:3339-3351.

Noble, M. S., and W. L. Hurley. 1999. Effects of secretion removal on bovine mammary gland function following an extended milk stasis. J. Dairy Sci. 82:1723-1730.

Nonnecke, B. J., and K. L. Smith. 1984. Inhibition of mastitic bacteria by bovine milk apo-lactoferrin evaluated by in vitro microassay of bacterial growth. J. Dairy Sci. 67:606-613.

Nørgaard, J. V., M. T. Sørensen, P. K. Theil, J. Sehested, and K. Sejrsen. 2008. Effect of pregnancy and feeding level on cell turnover and expression of related genes in the mammary tissue of lactating dairy cows. Animal 2:588-594.

Oliver, S. P., and K. L. Smith. 1982. Bovine mammary involution following intramammary infusion on colchicine and endotoxin at drying off. J. Dairy Sci. 65:801-813.

Oliver, S. P., and L. M. Sordillo. 1989. Approaches to the manipulation of mammary involution. J. Dairy Sci. 72:1647-1664.

Ollier, S., X. Zhao, and P. Lacasse. 2013. Effect of prolactin-release inhibition on milk production and mammary gland involution at drying-off in cows. J. Dairy Sci. 96:335-343.

Ollier, S., X. Zhao, and P. Lacasse. 2014. Effects of feed restriction and prolactin-release inhibition at drying off on metabolism and mammary gland involution in cows. J. Dairy Sci. 97:4942-4954.

Ollier, S., X. Zhao, and P. Lacasse. 2015. Effects of feed restriction and prolactin-release inhibition at drying-off on susceptibility to new intramammary infection in cows. J. Dairy Sci. 98:221-228.

Ossowski, L., D. Biegel, and E. Reich. 1979. Mammary plasminogen activator: Correlation with involution, hormonal modulation and comparison between normal and neoplastic tissue. Cell 16:929-940.

Otterlei, M., K. M. Vårum, L. Ryan, and T. Espevik. 1994. Characterization of binding and TNF- $\alpha$-inducing ability of chitosans on monocytes: The involvement of CD14. Vaccine 12:825-832.

Paape, M. J., W. P. Wergin, and A. J. Guidry. 1979. Leukocytes-Second line of defense against invading mastitis pathogens. J. Dairy Sci. $62: 135-153$

Peaker, M. 1977. Mechanism of milk secretion: Milk composition in relation to potential difference across the mammary epithelium. J. Physiol. 270:489-505. 
Peaker, M., and C. J. Wilde. 1996. Feedback control of milk secretion from milk. J. Mammary Gland Biol. Neoplasia 1:307-315.

Peters, R. R., and H. A. Tucker. 1978. Prolactin and growth hormone responses to photoperiod in heifers. Endocrinology 103:229-234.

Pezeshki, A., J. Mehrzad, G. R. Ghorbani, B. De Spiegeleer, R. J. Collier, and C. Burvenich. 2008. The effect of dry period length reduction to 28 days on the performance of multiparous dairy cows in the subsequent lactation. Can. J. Anim. Sci. 88:449-456.

Pitelka, D. R., B. N. Taggart, and S. T. Hamamoto. 1983. Effects of extracellular calcium depletion on membrane topography and occluding junctions of mammary epithelial cells in culture. J. Cell Biol. 96:613-624.

Plath-Gabler, A., C. Gabler, F. Sinowatz, B. Berisha, and D. Schams. 2001. The expression of the IGF family and GH receptor in the bovine mammary gland. J. Endocrinol. 168:39-48.

Politis, I., E. Block, and J. D. Turner. 1990. Effect of somatotropin on the plasminogen and plasmin system in the mammary gland: Proposed mechanism of action for somatotropin on the mammary gland. J. Dairy Sci. 73:1494-1499.

Politis, I., E. Lachance, E. Block, and J. D. Turner. 1989a. Plasmin and plasminogen in bovine milk: A relationship with involution? J. Dairy Sci. 72:900-906.

Politis, I., K. F. Ng Kwai Hang, and R. N. Giroux. 1989b. Environmental factors affecting plasmin activity in milk. J. Dairy Sci. $72: 1713-1718$

Ponchon, B., P. Lacasse, S. Ollier, and X. Zhao. 2017. Effects of photoperiod modulation and melatonin feeding around drying-off on bovine mammary gland involution. J. Dairy Sci. 100:8496-8506.

Ponchon, B., P. Lacasse, N. Silanikove, S. Ollier, and X. Zhao. 2014. Effects of intramammary infusions of casein hydrolysate, ethylene glycol-bis( $\beta$-aminoethyl ether)-N,N, $\mathrm{N}^{\prime}, \mathrm{N}^{\prime}$-tetraacetic acid, and lactose at drying-off on mammary gland involution. J. Dairy Sci. 97:779-788.

Pullan, S., J. Wilson, A. Metcalfe, G. M. Edwards, N. Goberdhan, J. Tilly, J. A. Hickman, C. Dive, and C. H. Streuli. 1996. Requirement of basement membrane for the suppression of programmed cell death in mammary epithelium. J. Cell Sci. 109:631-642.

Quarrie, L. H., C. V. P. Addey, and C. J. Wilde. 1996. Programmed cell death during mammary tissue involution induced by weaning, litter removal, and milk stasis. J. Cell. Physiol. 168:559-569.

Rabot, A., F. Sinowatz, B. Berisha, H. H. Meyer, and D. Schams. 2007. Expression and localization of extracellular matrix-degrading proteinases and their inhibitors in the bovine mammary gland during development, function, and involution. J. Dairy Sci. 90:740-748.

Rajala-Schultz, P. J., J. S. Hogan, and K. L. Smith. 2005. Short communication: Association between milk yield at dry-off and probability of intramammary infections at calving. J. Dairy Sci. 88:577-579.

Rothen-Rutishauser, B., F. K. Riesen, A. Braun, M. Günthert, and H. Wunderli-Allenspach. 2002. Dynamics of tight and adherens junctions under EGTA treatment. J. Membr. Biol. 188:151-162.

Ruel-Gariépy, E., and J.-C. Leroux. 2004. In situ-forming hydrogelsReview of temperature-sensitive systems. Eur. J. Pharm. Biopharm. 58:409-426.

Shamay, A., F. Shapiro, G. Leitner, and N. Silanikove. 2003. Infusions of casein hydrolyzates into the mammary gland disrupt tight junction integrity and induce involution in cows. J. Dairy Sci. $86: 1250-1258$.

Shamay, A., F. Shapiro, S. J. Mabjeesh, and N. Silanikove. 2002. Casein-derived phosphopeptides disrupt tight junction integrity, and precipitously dry up milk secretion in goats. Life Sci. 70:2707-2719.

Silanikove, N., A. Shamay, D. Shinder, and A. Moran. 2000. Stress down regulates milk yield in cows by plasmin induced beta-casein product that blocks $\mathrm{K}+$ channels on the apical membranes. Life Sci. 67:2201-2212.

Singh, K., J. Dobson, C. V. C. Phyn, S. R. Davis, V. C. Farr, A. J. Molenaar, and K. Stelwagen. 2005. Milk accumulation decreases expression of genes involved in cell-extracellular matrix communication and is associated with induction of apoptosis in the bovine mammary gland. Livest. Prod. Sci. 98:67-78.
Singh, K., K. M. Swanson, H. V. Henderson, R. A. Erdman, and K. Stelwagen. 2015. The effect of milking reinitiation following extended nonmilking periods on lactation in primiparous dairy cows. J. Dairy Sci. 98:7666-7674.

Sordillo, L. M., S. C. Nickerson, R. M. Akers, and S. P. Oliver. 1987. Secretion composition during bovine mammary involution and the relationship with mastitis. Int. J. Biochem. 19:1165-1172.

Sorensen, M. T., J. V. Nørgaard, P. K. Theil, M. Vestergaard, and K. Sejrsen. 2006. Cell turnover and activity in mammary tissue during lactation and the dry period in dairy cows. J. Dairy Sci. 89:4632-4639

Sorrell, A. M., J. H. Shand, E. Tonner, M. Gamberoni, P. A. Accorsi, J. Beattie, G. J. Allan, and D. J. Flint. 2006. Insulin-like growth factor-binding protein- 5 activates plasminogen by interaction with tissue plasminogen activator, independently of its ability to bind to plasminogen activator inhibitor-1, insulin-like growth factor-I, or heparin. J. Biol. Chem. 281:10883-10889.

Stanisiewski, E. P., N. K. Ames, L. T. Chapin, C. A. Blaze, and H. A. Tucker. 1988. Effect of pinealectomy on prolactin, testosterone and luteinizing hormone concentration in plasma of bull calves exposed to 8 or 16 hours of light per day. J. Anim. Sci. 66:464-469.

Stelwagen, K., S. R. Davis, V. C. Farr, C. G. Prosser, and R. A. Sherlock. 1994. Mammary epithelial cell tight junction integrity and mammary blood flow during an extended milking interval in goats. J. Dairy Sci. 77:426-432.

Stelwagen, K., V. C. Farr, S. R. Davis, and C. G. Prosser. 1995. EGTA-induced disruption of epithelial cell tight junctions in the lactating caprine mammary gland. Am. J. Physiol. 269:R848-R855.

Stelwagen, K., V. C. Farr, H. A. McFadden, C. G. Prosser, and S. R. Davis. 1997. Time course of milk accumulation-induced opening of mammary tight junctions, and blood clearance of milk components. Am. J. Physiol. 273:R379-R386.

Ster, C., M.-C. Loiselle, and P. Lacasse. 2012. Effect of postcalving serum nonesterified fatty acids concentration on the functionality of bovine immune cells. J. Dairy Sci. 95:708-717.

Strange, R., F. Li, S. Saurer, A. Burkhardt, and R. R. Friis. 1992 Apoptotic cell death and tissue remodelling during mouse mammary gland involution. Development 115:49-58.

Taherian, A. R., P. Lacasse, B. Bisakowski, M. Pelletier, S. Lanctôt, and P. Fustier. 2017. Rheological and thermogelling properties of commercials chitosan/ $\beta$-glycerophosphate: Retention of hydrogel in water, milk and UF-milk. Food Hydrocoll. 63:635-645.

Talhouk, R. S., M. J. Bissell, and Z. Werb. 1992. Coordinated expression of extracellular matrix-degrading proteinases and their inhibitors regulates mammary epithelial function during involution. J. Cell Biol. 118:1271-1282.

Tatarczuch, L., R. J. Bischof, C. J. Philip, and C. S. Lee. 2002. Phagocytic capacity of leucocytes in sheep mammary secretions following weaning. J. Anat. 201:351-361.

Tatarczuch, L., C. Philip, R. Bischof, and C. S. Lee. 2000. Leucocyte phenotypes in involuting and fully involuted mammary glandular tissues and secretions of sheep. J. Anat. 196:313-326.

Tonner, E., G. J. Allan, and D. J. Flint. 2000. Hormonal control of plasmin and tissue-type plasminogen activator activity in rat milk during involution of the mammary gland. J. Endocrinol. 167:265273.

Tonner, E., M. C. Barber, G. J. Allan, J. Beattie, J. Webster, C. B. A. Whitelaw, and D. J. Flint. 2002. Insulin-like growth factor binding protein-5 (IGFBP-5) induces premature cell death in the mammary glands of transgenic mice. Development 129:4547-4557.

Tonner, E., M. C. Barber, M. T. Travers, A. Logan, and D. J. Flint 1997. Hormonal control of insulin-like growth factor-binding protein-5 production in the involuting mammary gland of the rat. Endocrinology 138:5101-5107.

Travers, M. T., M. C. Barber, E. Tonner, L. Quarrie, C. J. Wilde, and D. J. Flint. 1996. The role of prolactin and growth hormone in the regulation of casein gene expression and mammary cell survival: Relationships to milk synthesis and secretion. Endocrinology 137:1530-1539. 
Tremblay, G., P. Bernier-Dodier, L. Delbecchi, G. F. Wagner, B. G. Talbot, and P. Lacasse. 2009. Local control of mammary involution: Is stanniocalcin-1 involved? J. Dairy Sci. 92:1998-2006.

Vanacker, N., S. Ollier, F. Beaudoin, R. Blouin, and P. Lacasse. 2017. Effect of inhibiting the lactogenic signal at calving on milk production and metabolic and immune perturbations in dairy cows. J. Dairy Sci. 100:5782-5791.

Velasco, J. M., E. D. Reid, K. K. Fried, T. F. Gressley, R. L. Wallace, and G. E. Dahl. 2008. Short-day photoperiod increases milk yield in cows with a reduced dry period length. J. Dairy Sci. 91:34673473.

Walker, N. I., R. E. Bennett, and J. F. R. Kerr. 1989. Cell death by apoptosis during involution of the lactating breast in mice and rats. Am. J. Anat. 185:19-32.

Wall, E. H., T. L. Auchtung, G. E. Dahl, S. E. Ellis, and T. B. McFadden. 2005. Exposure to short day photoperiod during the dry period enhances mammary growth in dairy cows. J. Dairy Sci. 88:1994-2003.
Watters, R. D., J. N. Guenther, A. E. Brickner, R. R. Rastani, P. M. Crump, P. W. Clark, and R. R. Grummer. 2008. Effects of dry period length on milk production and health of dairy cattle. J. Dairy Sci. 91:2595-2603.

Wen, Z.-S., Y.-L. Xu, X.-T. Zou, and Z.-R. Xu. 2011. Chitosan nanoparticles act as an adjuvant to promote both Th1 and Th2 immune responses induced by ovalbumin in mice. Mar. Drugs 9:1038-1055.

Weng, M. H., C. J. Chang, W. Y. Chen, W. K. Chou, H. C. Peh, M. C. Huang, M. T. Chen, and H. Nagahata. 2006. Contribution of somatic cell-associated activation of plasminogen to caseinolysis within the goat mammary gland. J. Dairy Sci. 89:2025-2037.

Wilde, C. J., C. V. P. Addey, P. Li, and D. G. Fernig. 1997. Programmed cell death in bovine mammary tissue during lactation and involution. Exp. Physiol. 82:943-953.

Yart, L., F. Dessauge, L. Finot, S. Barbey, P. G. Marnet, and V. Lollivier. 2012. Ovariectomy improves lactation persistency in dairy cows. J. Dairy Sci. 95:3794-3802. 